\title{
Use of Curcuma longa in cosmetics: extraction of curcuminoid pigments, development of formulations, and in vitro skin permeation studies
}

\author{
Gisele Mara Silva Gonçalves ${ }^{1, *}$, Gustavo Henrique da Silva ${ }^{1}$, Pedro Paulo Barros ${ }^{1}$, \\ Silvana Mariana Srebernich ${ }^{2}$, Cecilia Toyoko Cavalcanti Shiraishi', \\ Victória Rodrigues de Camargos ${ }^{1}$, Thais Barbiero Lasca ${ }^{1}$
}

${ }^{1}$ School of Pharmaceutical Science, Pontifícia Universidade Católica de Campinas, Campinas, SP, Brazil, ${ }^{2}$ School of Nutrition, Pontifícia Universidade Católica de Campinas, Campinas, SP, Brazil

\begin{abstract}
Curcuma longa is a ginger family aromatic herb (Zingiberaceae) whose rhizomes contain curcuminoid pigments, including curcumin, a compound known for its anti-inflammatory effects. The objective of this study was to obtain curcuminoid-rich extracts, develop topical formulations thereof, and assess the stability and skin permeation of these formulations. Curcuma longa extracts were obtained and used to develop formulations. Skin permeation studies were conducted in a modified Franz diffusion cell system, and skin retention of curcuminoid pigments was quantified in pig ear membrane. Prepared urea-containing gel-cream formulations were unstable, whereas all others had satisfactory stability and pseudoplastic rheological behavior. The amount of curcuminoid pigments recovered from the receptor solution was negligible. The skin concentration of curcuminoid pigments retained was positive $(>20 \mu \mathrm{g} / \mathrm{g}$ of skin, mostly in the stratum corneum), considering the low skin permeability of curcumin. We conclude that development of topical formulations containing curcumin or Curcuma longa extract is feasible, as long as adjuvants are added to improve preservation and durability. The formulations developed in this study enabled penetration of curcumin limited to the superficial layers of the skin and then possibly without a risk of systemic action, thus permitting local use as a topical anti-inflammatory.
\end{abstract}

Uniterms: Curcuma longa/pharmacognosy. Curcumin/use/topical anti-inflammatory. Cosmetics/use of natural products. Curcuminoid pigments. Skin penetration. Natural products/use in cosmetics.

Curcuma longa é uma erva aromática, pertencente à família Zingiberaceae e seus rizomas contêm pigmentos curcuminoides, dentre eles a curcumina, conhecida por seu efeito anti-inflamatório. O objetivo deste trabalho foi obter extratos ricos nestes pigmentos, desenvolver e avaliar a estabilidade de formulações tópicas e realizar o estudo da penetração cutânea. Extratos de Curcuma longa foram obtidos e utilizados no desenvolvimento de formulações. A penetração e retenção cutâneas de pigmentos curcuminoides foi avaliada em pele de orelha de porco, utilizando célula de difusão de Franz modificada. As formulações de gel creme preparadas que continham ureia foram instáveis e as demais apresentaram estabilidade satisfatória e comportamento reológico pseudoplástico. A quantidade de pigmentos curcuminoides encontrada na solução receptora foi insignificante, enquanto que a quantidade retida na pele foi superior a $20 \mu \mathrm{g} / \mathrm{g}$ de pele. Concluiu-se como possível o desenvolvimento de formulações tópicas contendo curcumina ou extrato de Curcuma longa, conciliando a adição de adjuvantes para a preservação e maior durabilidade da mesma. As formulações promoveram a penetração da curcumina limitada às camadas superiores da pele, possivelmente sem o risco de ocorrência de ação sistêmica sendo possível a sua utilização para ação local com atividade anti-inflamatória.

Unitermos: Curcuma longa/farmacognosia. Curcumina/uso/anti-inflamatório de ação local. Cosméticos/ uso de produtos naturais. Pigmentos curcuminoides. Retenção cutânea. Produtos naturais/uso em cosméticos.

\footnotetext{
*Correspondence: G.M.S.Gonçalves. Faculdade de Ciências Farmacêuticas, Pontifícia Universidade Católica de Campinas. Av. John Boyd Dunlop, s/n, Jardim Ipaussurama, 13060-904 - Campinas - SP, Brasil. E-mail: gmsg@puc-campinas.edu.br
} 


\section{INTRODUCTION}

There is great research interest in medicinal plants, which have been used from time immemorial by a variety of peoples for the treatment of illness (Yunes, Pedrosa, Cechinel Filho, 2001; Firmo et al., 2011). Approximately $30 \%$ of all drugs prescribed worldwide are still obtained directly or indirectly from plant sources (Koehn, Carter, 2005).

Curcuma longa (Zingiberaceae), commonly known as turmeric, is used as a spice (for its characteristic scent) and as a food coloring agent. The $C$. longa plant contains a rhizome, or main stem, with several offshoots or ramifications that have a distinctive orange color due to the presence of curcuminoid pigments (curcumin, demethoxycurcumin, bisdemethoxycurcumin, and cyclocurcumin). Curcumin is the major such pigment, and in vitro tests have demonstrated its antiparasitic, antispasmodic, and anti-inflammatory effects, as well as potential anticancer activity (Lin, Lin, 2008; Silva Filho et al., 2009).

According to Almeida (2006), C. longa rhizomes have been employed for their digestive, carminative, antispasmodic, antioxidant, antidiarrheal, diuretic, and stimulant action; in the treatment of liver disease; as a tonic; in the treatment of ulcers, cough, and the common cold; and even in ointment form to promote wound healing. Swanson et al. (2010) showed that C. longa extract has antioxidant effects and the ability to modulate inflammatory response. Hamzah (2011) assessed the antiinflammatory effect of curcumin extract topical gel in the carrageenan-induced albino rat paw edema model. At the end of the study, a 30\% reduction in edema was found in rats treated with the turmeric extract gel. Huang et al. (1997) found that topically applied curcumin was a potent inhibitor of induced skin tumor formation. Persistent inflammation, compounded by external factors such as pollution and solar radiation, increases the risk of skin tumorigenesis (Lin, Lin, 2008). Therefore, it is presumed that curcumin would be capable of preventing skin tumors and insults such as spots and wrinkles.

Achieving good skin permeation and, consequently, efficacy poses a challenge when developing formulations (Gupta, Dixit, 2011). Assessment of skin permeation is widely performed by means of a system known as the Franz diffusion cell (Dal'Belo, 2008). Use of the Franz diffusion cell provides information on the relationships between the substance of interest, its formulation, and the skin, thus aiding development of formulations that enable penetration of the active ingredient into the skin. In addition to human skin and synthetic membranes, pig skin can also be used in permeation studied due to its physiological and histological similarities to human skin, such as its overall morphology, the thickness and structure of the epidermis, thickness of the stratum corneum, and structure of the dermis. Pig ear skin is among the most widely used options (Dick, Scott,1992).

According to Pan et al. (2013) urea has been used with other medications as a penetration enhancing agent. Ginger rhizomes (Zingiber officinale) contain proteolytic enzymes similar to the action of papain and its extract could be used in topical formulations in order to facilitate the skin penetration of other substances (Gonçalves et al., in press).

The objective of the present study was to obtain curcumin-rich Curcuma longa extract, develop formulations thereof, and assess the skin permeation of curcuminoid pigments.

\section{MATERIAL AND METHODS}

\section{Material}

Curcumin from C. longa (turmeric) $(\geq 65 \%$ curcumin), urea and $\beta$-cyclodextrin were purchased from Sigma ${ }^{\mathrm{TM}}$ (St. Louis, MO, USA). Samples of $C$. longa were collected in August and September 2012 from a commercial plantation (São Paulo, Brazil). The plant was authenticated at the Pontifícia Universidade Católica de Campinas, Campinas, Brazil, by means of gross and microscopic analysis as set forth in the Brazilian Pharmacopoeia, 5ed.

Vegetal materials (Zingiber officinale rhizomes) were collected and identified at the Pontifícia Universidade Católica de Campinas, Campinas, SP, Brazil. After disinfecting with ethanol at $70.0 \%$, rhizomes were peeled and the juice was extracted using a juicer. The juice was filtered through a nylon filter and diluted using propyleneglycol and filtered again using a nylon filter. Next, it was centrifuged at $3000 \mathrm{rpm}$ for five minutes, and the supernatants were stored in amber glass and frozen until the moment of use (Gonçalves et al., in press).

Titanium dioxide and disodium EDTA were purchased from Labisynth (Diadema, SP, Brazil), Phenova ${ }^{\mathrm{TM}}$ (phenoxyethanol and parabens) from Croda (Campinas, SP, Brazil), Hydroxyethyl cellulose and Net FS TM (Polyglyceryl-10 myristate, triethylhexanoin, glycerin and water) from Galena (Campinas, SP, Brazil), and propylene glycol from Volp (Osasco, SP, Brazil).

Pig ear skins were obtained from an abattoir (Frigorífico Bressiani, Capivari, SP, Brazil). The skin was removed with surgical instruments. Then, the skin was 
wrapped in Parafilm ${ }^{\circledR}$ and aluminum foil and kept in a freezer for up to 30 days.

\section{Methods}

The present study was approved by the PUCCampinas Animal Research Ethics Committee with judgment no. CEUA 004/2012.

\section{Extraction}

Three C. longa extracts were obtained: hydroalcoholic extract (HE), dry extract (DE), and $\beta$-cyclodextrin extract (CE). For hydroalcoholic extraction, rhizomes were processed by turbo-extraction in ethanol ( 1 part rhizome: 5 parts solvent). The resulting extract (HE) was filtered in nylon and stored in an amber glass bottle under refrigeration. For dry extraction, the rhizomes were refluxed in ethanol for 2 hours, filtered, reduced in a rotary evaporator, and desiccated in an air-circulation drying oven at $50^{\circ} \mathrm{C}$ (Almeida, 2006). For $\beta$-cyclodextrin extract, $1 \mathrm{~g}$ cyclodextrin and $20 \mathrm{~mL}$ HE were added to a beaker and kept under constant agitation for 24 hours. The resulting extract (CE) was vacuum-filtered (Wang et al., 2011). The loading rate of curcuminoid pigments in $\beta$-cyclodextrin was estimated by comparing the absorbance of the extract at $425 \mathrm{~nm}$ before and after the procedure ( $1 \mathrm{~g} \beta$-cyclodextrin contained approximately $40 \mu \mathrm{g}$ curcuminoid pigments).
The total curcuminoid pigment concentration of the refrigerated $\mathrm{HE}$ and of the DE was quantified over 120 days, in triplicate, taking into account absorbance at $425 \mathrm{~nm}$ (measured on a Varian Cary 50 Bio UV/Vis spectrophotometer) and an analytical curve obtained for curcumin at $10,20,40,80$, and $100 \mu \mathrm{g} / \mathrm{mL}$. All samples were diluted in ethanol and filtered in a 0.45 -micron Millex ${ }^{\circledR}$ membrane.

\section{Development and assessment of the formulations}

Formulations 1 to 12 were prepared by heating the water and hydroxyethylcellulose, under stirring, to $70{ }^{\circ} \mathrm{C}$ for gel formation. Propylene glycol, phenoxyethanol and parabens, Dissodium EDTA were added and the Polyglyceryl 10-myristate, triethylhexanoin, glycerin and water, homogenizing under constant stirring. The other ingredients were added in the cold cream gel (urea, $\beta$-cyclodextrin, $\beta$-cyclodextrin/HE, HE, DE, Ginger extract and/or curcumin). For the preparation of the formulation 13, the method was similar, but titanium dioxide was dispersed in the propylene glycol before being added to the formulation.

Formulations (Table I) were stored in PVC containers (37 $\mathrm{mm}$ in diameter $\mathrm{x} 29 \mathrm{~mm}$ deep) and in Borel glass bottles at 40,60 , and $\sim 25^{\circ} \mathrm{C}$ for up to 28 days. Appearance, $\mathrm{pH}$, color, odor, and viscosity were assessed at 7-day intervals as described in the Guia de Controle

TABLE I - Formulations

\begin{tabular}{|c|c|c|c|c|c|c|c|c|c|c|c|c|c|}
\hline \multirow{2}{*}{ Components (INCI*) } & \multicolumn{13}{|c|}{ Formulation / amount $(\% \mathrm{w} / \mathrm{w})$} \\
\hline & 1 & 2 & 3 & 4 & 5 & 6 & 7 & 8 & 9 & 10 & 11 & 12 & 13 \\
\hline Urea & 5.0 & 5.0 & - & 5.0 & 5.0 & 5.0 & 5.0 & - & - & - & - & - & - \\
\hline$\beta$-Cyclodextrin & - & - & - & 2.0 & - & 2.0 & - & 2.0 & - & - & - & - & - \\
\hline $\mathrm{CE}$ & - & - & 2.0 & - & 2.0 & - & - & - & 2.0 & - & - & - & - \\
\hline $\mathrm{HE}$ & 0.5 & - & - & & - & - & - & - & - & - & - & - & - \\
\hline $\mathrm{DE}$ & - & - & - & - & - & - & - & - & - & - & 0.1 & 0.1 & 0.1 \\
\hline Ginger extract & - & - & - & - & - & - & - & - & & - & - & 20.0 & - \\
\hline Curcumin & - & - & - & - & - & - & 0.1 & - & - & 0.1 & - & - & - \\
\hline Titanium dioxide & - & - & - & - & - & - & - & - & - & - & - & - & 1.0 \\
\hline Hydroxyethyl cellulose & \multicolumn{13}{|c|}{1.8 (all formulations) } \\
\hline $\begin{array}{l}\text { Polyglyceryl-10 myristate, triethylhexanoin, } \\
\text { glycerin, water }\end{array}$ & \multicolumn{13}{|c|}{2.0 (all formulations) } \\
\hline Propylene glycol & \multicolumn{13}{|c|}{5.0 (all formulations) } \\
\hline phenoxyethanol and parabens & \multicolumn{13}{|c|}{0.8 (all formulations) } \\
\hline Disodium EDTA & \multicolumn{13}{|c|}{0.01 (all formulations) } \\
\hline Aqua & \multicolumn{13}{|c|}{ To 100 (all formulations) } \\
\hline
\end{tabular}

* International Nomenclature of Cosmetic Ingredients (CE, $\beta$-cyclodextrin extract; HE, hydroalcoholic extract; DE, dry extract). 
de Qualidade de Produtos Cosméticos (2008) and in the Guia de Estabilidade de Produtos Cosméticos (2004), publications of the National Health Surveillance Agency, an autonomous department of the Brazilian government. The $\mathrm{pH}$ of the formulations diluted with water to one-tenth of their original concentrations was determined with a Digimed $\mathrm{pH}$ meter. Color and appearance were assessed by a visual method and olfaction. These assessments took into consideration the initial attributes of the formulations and changes that may or may not have occurred during the study period.

Physical stability was assessed by rheological determinations done on an RTV Brookfield rotational viscometer (Stoughton, MA, USA). Viscosity parameters were determined at $25{ }^{\circ} \mathrm{C}$ using a number 5 spindle for each sample $24 \mathrm{~h}$ after preparation, and at regular intervals over the storage period. Samples were tested with rotation speeds that increased progressively (1-5 rpm). Each reading was done 120 seconds after the new rotation speed.

\section{In vitro skin permeation and retention studies}

Skin permeation was assayed in an open diffusion system based on a Franz cell apparatus design coupled to a water circulator at $36^{\circ} \mathrm{C}\left(\mathrm{PCB} 150\right.$ Water Peltier System $\left.{ }^{\circledR}\right)$. The Franz cell used was custom made. The experimental conditions were as follows: receptor solution, $100 \mathrm{~mL}$ phosphate buffer ( $\mathrm{pH}$ 7.4) under constant agitation; diffusion membrane, pig ear skin (previously hydrated in phosphate buffer [pH 7.4] and attached to a circular support $27 \mathrm{~mm}$ in diameter); donor solution, $5 \mathrm{~g}$ study formulation. During the experiment, $1.5 \mathrm{~mL}$ aliquots of receptor solution were collected at $30 \mathrm{~min}, 1 \mathrm{~h}, 2 \mathrm{~h}$, and $3 \mathrm{~h}$ for measurement spectrophotometrically at $425 \mathrm{~nm}$. The method used was based on the traditional method, but was adapted by the authors, due to the experimental conditions.

Assessment of skin retention of curcuminoid pigments was performed on whole skin and by the tapestripping method, whereby the stratum corneum and the rest of the skin are evaluated separately (Banga, Abla, 2013). For the tape-stripping method, 15 fragments of $3 \mathrm{M}^{\circledR}$ adhesive tape were applied and removed. The pigments retained on the tape were then extracted and quantitated, and the remaining skin was homogenized and assayed as below. For the first assessment, after the end of the skin permeation experiment, the skin was removed, wiped with water-soaked cotton wool, homogenized with $100 \mathrm{~mL}$ ethanol and reduced in a rotary evaporator until $20 \mathrm{~mL}$. The resulting maceration solution was filtered and the concentration of curcuminoid pigments spectrophotometrically quantitated at $425 \mathrm{~nm}$.
To prevent interference from other substances contained in the skin, a control sample of skin was assessed under the same conditions. No placebo control was used, because no vehicle components exhibited absorption at the wavelength of interest.

\section{RESULTS AND DISCUSSION}

The identity of the plant material was confirmed by gross and microscopic examination. The rhizomes were oval-shaped, tan to brownish yellow, and covered in ring-shaped scars (Figure 1). Transection revealed orange-yellow rhizomes with clear structural separation into two zones, the cortex and the inner core, separated by the endodermoid layer.

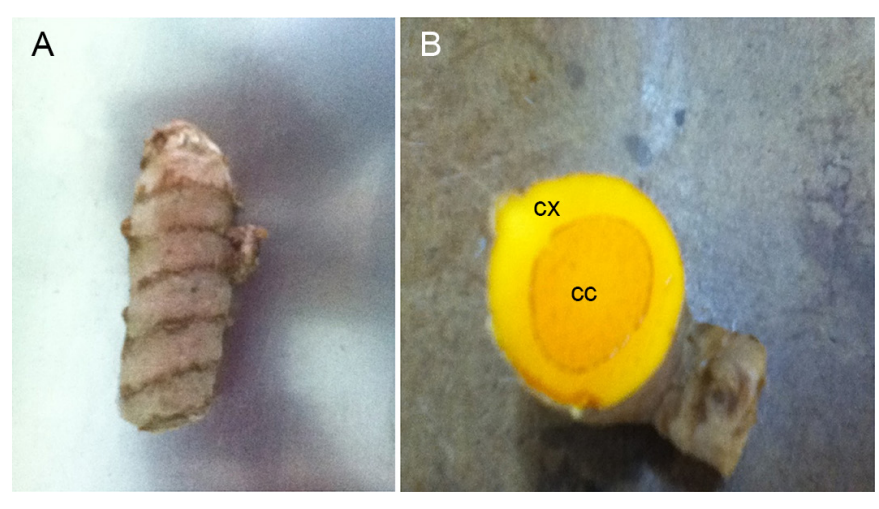

FIGURE 1 - Curcuma longa rhizome. a) Whole rhizome; b) cross-section (cx, cortex; cc, central cylinder).

Microscopic analysis (Figure 2) revealed the cuticle, parenchyma, vascular bundles, xylem with spiral thickening, and phloem, as expected for C. longa. The total water content was $20 \%$, which is consistent with the findings of Leonel and Cereda (2002).

The epidermis (e) is made up of tangentially flattened cells, most tabular and thin-walled. The cork (s) is visible below, consisting of rectangular cells, much larger than those of the epidermis, compact, with radially disposed, suberized walls, followed by the cortical parenchyma (p).

Ethanol was used for extraction of curcuminoid pigments in view of its solubility (Tapal, Tiku, 2012). The resulting extract (HE) had a concentration of approximately $330 \mu \mathrm{g} / \mathrm{mL}$ (Table II), as estimated on the basis of all measurements over a 120-day period, thus demonstrating the stability of this extract. The DE had a concentration of $488.6 \mathrm{mg}$ curcuminoid pigments per g extract. The obtained extract was yellow and had a faint, distinctive odor of saffron. Paulucci et al. (2013) concluded that a superior extraction yield was obtained 


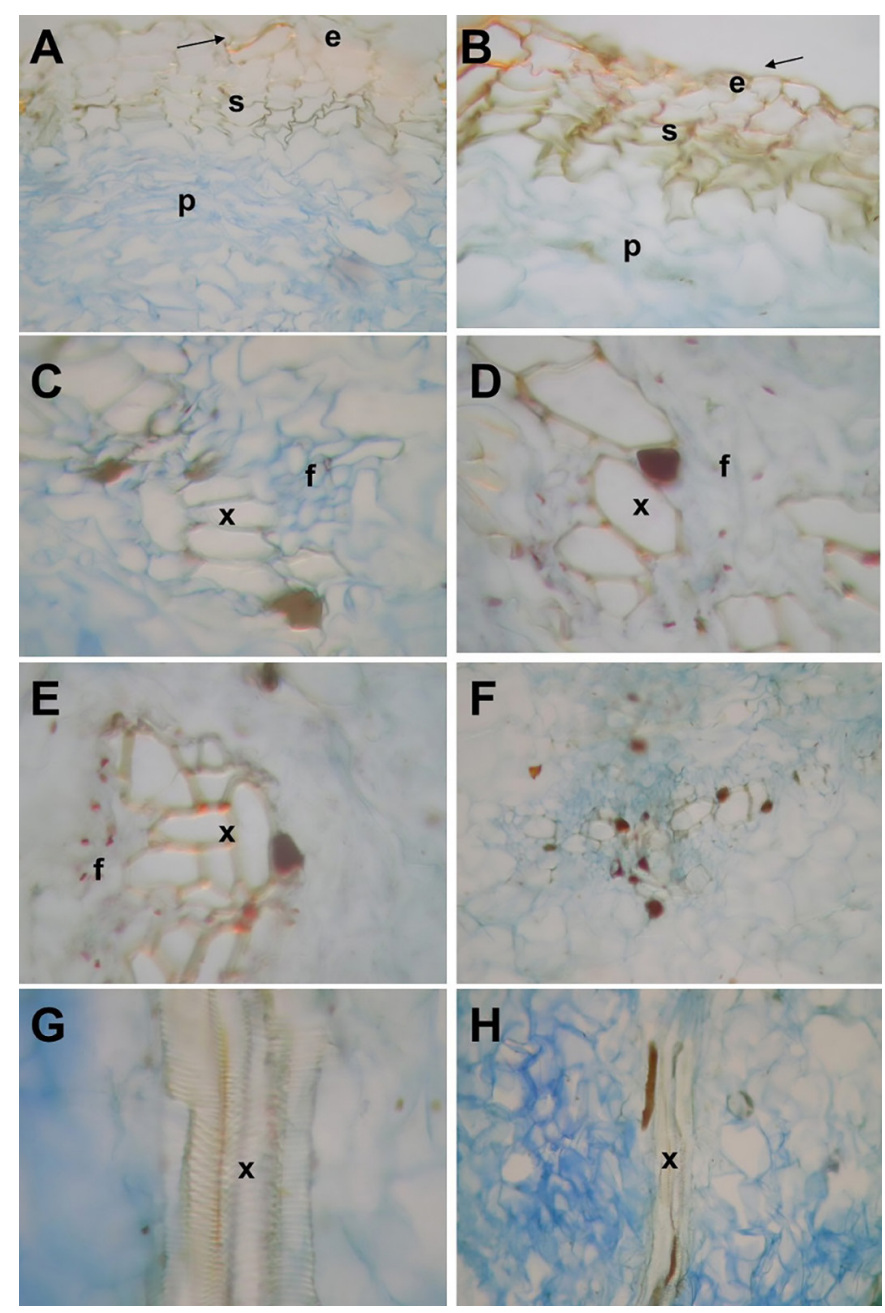

FIGURE 2 - Micrographs of Curcuma longa L rhizome sections. $\mathbf{A}$ and B: Cross-section showing smooth, thin cuticle (arrows). Epidermis (e), cork (s), cortical parenchyma (p). C, D and E: Cross-sections showing collateral vascular bundles, xylem (x) and phloem (f). F: Panoramic micrograph of the bundle. G and $\mathbf{H}$ : Micrographs showing scalariform vessels (longitudinal section). Masson's trichrome. A-E and G, original magnification 400x; F and H, original magnification 200x.

with $70 \%$ ethanol for dry curcumin (powder), which yielded curcumin concentrations of $0.1-1.8 \%$. The difference between the method used by these authors and ours was the longer extraction time.

Over the course of the study, 13 gel-cream formulations were developed (Table I), containing various combinations of urea, curcumin, $\mathrm{HE}, \mathrm{DE}$, and CE, among other components, so as to compare their stability and the skin permeation of curcuminoid pigments. We chose to add curcumin at the $0.1 \%$ concentration to prevent the color of the formulations from being overly bright. HE and DE were used at the $2 \%$ and $0.1 \%$ concentrations respectively, due to differences in the amount of curcuminoid pigments
TABLE II - Mean concentration of curcuminoid pigments in Curcuma longa hydroalcoholic extract as a function of storage time under refrigeration $(n=3)$. Quantitated by spectrophotometry at $425 \mathrm{~nm}$

\begin{tabular}{lc}
\hline Time (days) & Curcuminoid pigments $(\mu \mathrm{g} / \mathrm{mL})$ \\
\hline Baseline & $375 \pm 1,68$ \\
30 & $335 \pm 1,74$ \\
40 & $330 \pm 3,25$ \\
60 & $335 \pm 2,78$ \\
120 & $310 \pm 3,57$ \\
\hline
\end{tabular}

present in each extract, whereas urea was used at a $5 \%$ concentration.

The initial $\mathrm{pH}$ of all formulations was slightly acidic at $\geq 5$.5. The formulations containing urea showed changes in $\mathrm{pH}$ (5.4 to 8.5) during 14 days of storage. Formulations without urea showed more stable $\mathrm{pH}$ (5.5 to 6.0) for 28 days of storage. As curcumin is more stable in slightly acidic environments (Gupta, Dixit, 2011) and the values found were close to skin $\mathrm{pH}$, this finding was considered favorable and no adjustment was required. However, after 14 days in storage, some formulations exhibited changes in $\mathrm{pH}$. All of these formulations contained urea, which was added in an attempt to facilitate skin penetration of curcumin by keratolysis and consequent reduction of the skin barrier (Addor et al., 2009). However, over the course of the stability study, this combination was found to jeopardize the stability of the formulations. Therefore, the addition of urea was ruled out and all urea-containing formulations were disregarded.

We also assessed $\beta$-cyclodextrin incorporation of the $\mathrm{HE}$, as, given the hydrophilic nature of their outer surface, $\beta$-cyclodextrins are capable of dissolving in water while providing an apolar cavity that can bind several molecules, including curcumin (Araujo et al., 2006). In the present study, the $\beta$-cyclodextrin-containing formulations were considered stable; formulation 5 , which contained both urea and the $\beta$-cyclodextrin/HE complex, had a $\mathrm{pH}$ of 6.1 at the time of compounding and a $\mathrm{pH}$ of 8.7 after 14 days in storage, which led to its exclusion from the study. Conversely, the formulation that contained the $\beta$-cyclodextrin/HE complex remained stable and was thus kept in the sample.

Curcumin encapsulation has been studied by many authors in an attempt to increase absorption of this substance. Mazzarino (2009) produced lipid and polymer nanocapsules containing curcumin at concentrations of $127.04-509.49 \mu \mathrm{g} / \mathrm{mL}$. Encapsulation protects the product from degradation and other interactions, and is expected 
TABLE III - Mean concentrations of curcuminoid pigments $(\mu \mathrm{g} / \mathrm{mL})$ in $1.5 \mathrm{~mL}$ aliquot of receptor solution during in vitro skin permeation studies of different formulations for topical use containing curcumin or hydroalcoholic Curcuma longa extract, using pig ear skin in a modified Franz diffusion cell

\begin{tabular}{lcccc}
\hline \multirow{2}{*}{ Formulation } & \multicolumn{4}{c}{ Concentration of curcuminoid pigments $(\mu \mathrm{g} / \mathrm{mL})$ in receptor solution } \\
\cline { 2 - 5 } & $30 \mathrm{~min}$ & $1 \mathrm{~h}$ & $2 \mathrm{~h}$ & $3 \mathrm{~h}$ \\
\hline 1 & 2.25 & 2.73 & 3.96 & 4.58 \\
10 & 2.12 & 2.71 & 3.48 & 4.06 \\
11 & 1.56 & 2.11 & 3.14 & 5.13 \\
12 & 1.71 & 1.17 & 1.40 & 1.61 \\
\hline
\end{tabular}

to produce a more stable formulation. Other studies have assessed a broad range of curcumin encapsulation techniques, using a variety of capsule sizes and solubility values, usually in an attempt to increase bioavailability and thus enable therapeutic use of curcumin (Wang et al., 2011).

Regarding color and odor, only the formulations kept at $50^{\circ} \mathrm{C}$ exhibited any changes in these parameters after 28 days of storage, except for the inert formulation (number 8). The most stable formulation was number 13, which contained titanium dioxide. Monitoring of organoleptic characteristics is a routine aspect of product development. Within this context, Gonçalves et al. (2013) reported a similar dark discoloration of gel-cream formulations containing Thymus vulgaris, essential oil, which was attributed to the high storage temperature and is indicative of potential product instability.

On rheological assays, all formulations exhibited pseudoplastic behavior, as expected. All tested formulations remained stable in this respect due to the study period, as there were no peaks and the rheogram curves for each formulation remained similar at each time point of storage. These findings are consistent with those reported by Gonçalves and Maia Campos (2009), who studied vitamin C-containing formulations and also found no peaks in the viscosity plots of stable formulations, as well as Peraro (2001) who studied O/W emulsions and also the rheology of the formulations evaluated.

Formulation 11, which contained DE, and formulation 12, which contained DE and ginger extract, exhibited discoloration and a stronger scent over the course of the study. Ginger extract was added to this formulation in an attempt to ascertain whether proteolytic enzymes might enhance skin penetration of curcuminoid pigments (Gonçalves et al., in press). Comparing this finding with those obtained for formulations containing curcumin standard or HE, and bearing in mind that decomposition of most cosmetic formulations follows first-order kinetics, shows that increasing concentrations increased the speed of product decomposition. Therefore, as the formulations made from DE or pure curcumin contained higher pigment concentrations than those made from $\mathrm{HE}$, this may at least partly explain the faster loss of stability as demonstrated by product discoloration.

One formulation included titanium dioxide as a whitening agent in an attempt to improve the appearance of the product. This formulation was not tested for rheological behavior, but viscosity was apparently unchanged; furthermore, its $\mathrm{pH}$, color, and scent remained stable, and it was thus considered the most stable formulation. Furthermore, it was the only formulation that did not produce yellow discoloration of the skin on topical application.

The results of skin penetration testing showed that curcumin could not be recovered until $3 \mathrm{~h}$ at substantial amounts from the receptor solution with any of the assessed formulations (Table III). Several authors have used this experimental model to assess the bioavailability of transdermal formulations (Darwheka, Jain, Patidar, 2011). As systemic absorption of cosmetics is entirely undesirable, extrapolation of this finding to real-world use of the product suggests that absorption of the formulation would not occur, which may be regarded as an advantage. However, the method does not allow this claim because there is no determination of curcumin in the blood.

Conversely, our findings do show that curcuminoid pigments were retained in the skin (Tables IV and V).

TABLE IV - Curcuminoid pigments retained in the skin $(\mu \mathrm{g} / \mathrm{mL})$. Pigments were recovered by maceration in $100 \mathrm{ml}$ ethanol, the volume was reduced to $20 \mathrm{~mL}$ and quantification performed by spectrophotometry

\begin{tabular}{lc}
\hline Formulation & $\begin{array}{c}\text { Amount of curcuminoid pigments } \\
\text { retained in skin }\end{array}$ \\
\hline 1 & 5.70 \\
10 & 3.65 \\
11 & 15.03 \\
12 & 1.72 \\
\hline
\end{tabular}


TABLE V - Mean concentrations of curcuminoid pigments in pig ear skin ( $\mu$ g pigment/g skin) during in vitro skin permeation studies of different formulations containing curcumin or hydroalcoholic Curcuma longa extract in a modified Franz diffusion cell. Curcuminoid pigments were recovered by homogenization and tape stripping

\begin{tabular}{lccc}
\hline \multirow{2}{*}{ Formulation } & \multicolumn{3}{c}{ Amount of curcuminoid pigments retained in skin } \\
\cline { 2 - 4 } & Whole skin homogenization & Tape stripping & Skin homogenization after tape stripping \\
\hline 10 & 77.99 & 274.4 & 19.08 \\
11 & 25.72 & 22.24 & $\mathrm{NP}$ \\
12 & 32.48 & 27.05 & 47.00 \\
13 & 21.75 & $\mathrm{NP}$ & $\mathrm{NP}$ \\
\hline
\end{tabular}

NP, not performed.

Formulation 9, which contained a $\beta$-cyclodextrin/HE complex, was also associated with insignificant skin retention, suggesting that encapsulation was not helpful in this setting. Formulation 1, which contained HE, also performed poorly due to a low concentration of curcuminoid pigments, whereas the formulation made from DE exhibited somewhat higher skin retention.

The results of this study show that formulation 10 had the greatest skin retention, despite containing no substances that could facilitate skin permeation. However, this formulation was made from $0.1 \%$ curcumin standard. Formulation 12, which contained ginger extract, had a lower rather than higher concentration of curcuminoid pigments. Therefore, the hypothesis that ginger extract might enhance skin permeation or retention of curcumin was ruled out. Formulation 11, made with DE, had lower concentrations than formulation 10 . As formulation 13 and formulation 11 had very similar compositions, the former was not tested in this assay.

The tape-stripping method has been used to assess the depth of skin penetration of a variety of substances. In the present study, it revealed curcuminoid pigments in the epidermis and in the outer layer of the dermis, assuming complete stripping of the epidermis on tape removal (Banga, Abla, 2013).

According to Zhang et al. (2013), who studied encapsulation of active ingredients in tyrosine-derived nanospheres and skin retention of such preparations, the amount of active ingredient retained in the skin was in the $\mathrm{ng} / \mathrm{cm}^{2}$ range. In the present study, greater retention was observed, in the $\mu \mathrm{g} / \mathrm{g}$ range; results were expressed in grams of skin because non-dermatomed pig ear skin has variable thickness $(0.95-1.45 \mathrm{~mm}$ in this study). In another investigation, skin retention of liposomeencapsulated curcumin was in the $\mu \mathrm{g} / \mathrm{cm}^{2}$ range in experiments with a duration of up to 50 hours (Chen et al., 2012). Parameters that affect the skin permeation of a substance and should be taken into account include the size of the molecule, its polarity, and its partition coefficient. As curcumin does not have the ideal characteristics for optimal skin penetration, our results can be regarded as very good, particularly as the formulations tested herein are not meant to be systemically absorbed. Therefore, the skin retention values presented may be considered positive in terms of achieving the desired effects of the test substance, particularly its anti-inflammatory effect.

Finally, after analyzing the distribution of curcuminoid pigments in the skin, we conclude that the formulation delivers a significant amount of curcumin to the epidermis and dermis. Furthermore, as the concentration recovered from the receptor solution was negligible, we conclude that the active ingredient was delivered into the basal layer of the epidermis and the upper layer of the dermis. These are usually the target skin layers for active ingredient delivery in cosmetics and personal care formulations, as systemic absorption of this class of products is undesirable.

\section{CONCLUSION}

The HE had a curcuminoid pigment concentration of approximately $300 \mu \mathrm{g} / \mathrm{mL}$, and the $\mathrm{DE}$, a concentration of $488.6 \mathrm{mg} / \mathrm{g}$. The most stable were formulation 9 (made from the $\beta$-cyclodextrin/HE complex) and 13 (made from the DE), whereas the urea-containing formulations were least stable. Cyclodextrin encapsulation of the HE increased formulation stability, but reduced the amount of pigment retained in the skin. Skin retention of curcuminoid pigments was in the $\mu \mathrm{g} / \mathrm{g}$ range, with different values for each of the tested formulations. Those formulations containing extracts obtained from Curcuma longa rhizomes performed poorly in comparison with that using $0.1 \%$ standard curcumin, due to a lower concentration of curcuminoid pigments or curcumin. Skin penetration by curcumin was low, but skin retention did occur, making curcumin a very promising compound for use in anti-aging formulations. 


\section{ACKNOWLEDGEMENTS}

The authors would like to thank CNPq and FAPIC/ Reitoria for undergraduate research scholarships and PUC-Campinas for providing infrastructure and support.

\section{REFERENCES}

ADDOR, F.A.S.; SCHALKA, S.; PEREIRA, V.M.C.; FOLINO, B.B. Correlação entre o efeito hidratante da ureia em diferentes concentrações de aplicação: estudo clínico e corneométrico. Surgical Cosmetic Dermatol., v.1, n.1, p.5-9, 2009.

ALMEIDA, L.P. Caracterização de pigmentos da Curcuma longa L., avaliação da atividade antimicrobiana, morfogênese in vitro na produção de curcuminóides e óleos essenciais. Belo Horizonte, 2006. 120 p. [Thesis of PhD degree. Faculty of Pharmaceutical Sciences, Federal University of Minas Gerais].

ARAUJO, D.R.; BRAGA,A.F.A.; MORAES, C.M.; FRACETO, L.F.; PAULA, E. Mistura com excesso enantiomérico de 50\% (S75-R25) de bupivacaína complexada com ciclodextrinas e anestesia por via subaracnóidea em ratos. Rev. Bras. Anestesiol., v.56, n.5, p.495-506, 2006.

BANGA, A.K.; ABLA, M.J. Quantification of skin penetration of antioxidants of varying lipophilicity. Int. J. Cosmet. Sci., v.35, n.1, p.19-26, 2013.

BRAZILIAN PHARMACOPOEIA. 5ed. Brasília: Agência Nacional de Vigilância Sanitária, 2010.891 p.

CHEN, Y.; WU, Q.; ZHANG, Z.; YUAN, L.; LIU, X.; ZHOU, L. Preparation of curcumin-loaded liposomes and evaluation of their skin permeation and pharmacodynamics. Molecules, v.17, n.5, p.5972-5987, 2012.

DAL'BELO, S.E. Avaliação da eficácia fotoprotetora, penetração cutânea e segurança de formulações cosméticas contendo extratos de chá verde e Ginkgo biloba. Ribeirão Preto, 2008. 176 p. [Thesis of PhD degree. Faculty of Pharmaceutical Sciences of Ribeirão Preto, University of São Paulo].

DARWHEKA, G.; JAIN, D.K.; PATIDAR, V.K. Formulation and evaluation of transdermal drug delivery system of clopidogrel bisulfate. Asian J. Pharm. Life Sci., v.1, n.3, p.269-278, 2011.
DICK, I.P., SCOTT, R.C. Pig ear skin as an in vitro model for human skin permeability. J. Pharm. Pharmacol., v.44, n.8, p.640-645, 1992.

FIRMO, W.C.A.; MENEZES, M.J.M.; PASSOS, C.E.C.; DIAS ALVES, L.P.L.; DIAS, I.C.L.; NETO, M.S.; OLEA, R.S.G. Historical context, popular use and scientific conception on medicinal plants. Cad. Pesq., São Luís, v.18, n.especial, p.90-95, 2011.

GONÇALVES, G.M.S.; MAIA CAMPOS, P.M.B.G. Shelf life and rheology of emulsions containing vitamin $\mathrm{C}$ and its derivatives. Rev. Ciênc. Farm. Básica Apl., v.30, n.2, p.217-224, 2009.

GONÇALVES, G.M.S.; SILVA, G.H.; BARROS, P.P.; SREBERNICH, S.M.; TONON, F.R.; FIORE, D.S. Antimicrobial effect and enzymatic activity of extract of Zingiber officinale roscoe and stability in topical preparations. Rev. Ciênc. Farm. Básica Apl., v.35, n.2, p.205-210, 2014.

GONÇALVES, G.M.S.; SREBERNICH, S.M.; BRAGAGNOLO, N.; MADALOZZO, E.S.; MERHI, V.L.; PIRES, D.C. Study of the composition of Thymus vulgaris essential oil, developing of topic formulations and evaluation of antimicrobial efficacy. J. Med. Plants Res., v.7, n.23, p.1736-1745, 2013.

GUIA DE CONTROLE DE QUALIDADE DE PRODUTOS COSMÉTICOS. Uma abordagem sobre os ensaios físicos e químicos. 2008. Agência Nacional de Vigilância Sanitária. Available at: www.anvisa.gov.br. Accessed on: 10 Jun. 2013.

GUIA DE ESTABILIDADE DE PRODUTOS COSMÉTICOS. Séries temáticas, volume 1, maio de 2004. Agência Nacional de Vigilância Sanitária. Available at: www.anvisa.gov.br. Accessed on: 10 Jun. 2013.

GUPTA, N.K.; DIXIT, V.K. Development and evaluation of vesicular system for curcumin delivery. Arch Dermatol Res., v.303, n.2, p.89-101, 2011.

HAMZAH, M.M. Evaluation of topical preparations containing curcuma, acacia and lupinus extracts as an antiinflammatory drugs. Int. J. Appl. Res. Nat. Prod., v.4, n.2, p.19-23, 2011. 
HUANG, M.T.; MA, W.; YEN, P.; XIE, J.G.; HAN, J.; FRENKEL, J.; GRUNBERGER, D.; CONNEY, A.H. Inhibitory effects of topical application of low doses of curcumin on 12-O-tetradecanoylphorbol-13-acetateinduced tumor promotion and oxidized DNA bases in mouse epidermis. Carcinogenesis, v.18, n.1, p.83-88, 1997.

INSTITUTO ADOLFO LUTZ. Normas Analíticas do Instituto Adolfo Lutz: métodos físico-químicos para análise de alimentos. 4.ed. Brasília: Imprensa Oficial do Estado, 2005. chap.V, p.219-223.

KOEHN, F.E.; CARTER, G.T. The evolving role of natural products in drug discovery. Nat. Rev. Drug Discov., v.4, n.3, p.206-220, 2005.

LEONEL, M.; CEREDA, M.P. Caracterização físico-química de algumas tuberosas amiláceas. Ciênc. Tecnol. Aliment., v.22, n.1, p.65-69, 2002.

LIN, C.L.; LIN, J.K. Curcumin: a potential cancer chemopreventive agent through suppressing NF-1B signaling. J. Cancer Mol., v.4, n.1, p.11-16, 2008.

MAZZARINO, L. Desenvolvimento de sistemas nanoestruturados contendo curcumina e avaliação in vitro $e$ in vivo em modelo de melanoma murino B16-F10. Florianópolis, 2009. 155 f. [Dissertion of Master degree. Faculty of Pharmaceutical Sciences, Federal University of Santa Catarina].

PAN, M.; HEINECKE, G.; BERNARDO, S.; TSUI, C.; LEVITT, J. Urea: a comprehensive review of the clinical literature (review). Dermatol. Online J., v.19, n.11, 2013.

PAULUCCI, V.P.; COUTO, R.O.; TEIXEIRA, C.C.C.; FREITAS, L.A.P. Optimization of the extraction of curcumin from Curcuma longa rhizomes. Rev. Bras. Farmacogn., v.23, n.1, p.94-100, 2013.
PERARO, A.C. Estabilidade física e metodologia analítica para formulações farmacêuticas contendo cetoconazol. São Paulo, 2001. 116 p. [Dissertation of Master degree. Faculty of Pharmaceutical Sciences, University of São Paulo].

SILVA FILHO, C.R.M.; SOUZA, A.G.; CONCEIÇÃO, M.M.; SILVA, T.G.; SILVA, T.M.S.; RIBEIRO, A.P.L. Avaliação da bioatividade dos extratos de cúrcuma (Curcuma longa L., Zingiberaceae) em Artemia salina e Biomphalaria glabrata. Rev. Bras. Farmacogn., v.19, n.4, p.919-923, 2009.

SWANSON, C.L.; LAUGHLIN, L.T.; FINLAY, D.; ROBINSON, M.K.; REICHLING, T.D.; MATHENY, H.E.; BUSHNELL, D.S. Biomarker analysis confirms the antioxidant and antiinflammatory activity of a colorless turmeric extract in vitro. J. Am. Acad. Dermatol., v.62, n.3, sup.1, p.AB23, 2010.

TAPAL, A.; TIKU, P.K. Complexation of curcumin with soy protein isolate and its implications on solubility and stability of curcumin. Food Chem., v.130, n.4, p.960-965, 2012.

WANG, S.; TAN, M.; ZHONG, Z.; CHEN, M.; WANG, Y. Nanotechnologies for curcumin: an ancient puzzler meets modern solutions. J. Nano Nanomat., v.2011, p.1-8, 2011.

YUNES, R.A.; PEDROSA, R.C.; CECHINEL FILHO, V. Fármacos e fitoterápicos: A necessidade do desenvolvimento de fitoterápicos e fitofármacos no Brasil. Quím. Nova, v.24, n.1, p.147-152, 2001.

Received for publication on $07^{\text {th }}$ December 2013 Accepted for publication on $18^{\text {th }}$ June 2014 
